\title{
PENGARUH KONSENTRASI MALEAT ANHIDRIDA TERHADAP MUTU PAPAN PARTIKEL YANG DIBUAT DARI LIMBAH PADAT Gracilaria sp. DAN POLIETILEN SEBAGAI PEREKAT
}

\author{
Diini Fithriani*), Jamal Basmal ${ }^{*}$, dan Bagus Sediadi Bandol Utomo*)
}

\begin{abstract}
ABSTRAK
Tujuan penelitian ini adalah untuk mempelajari pengaruh maleat anhidrida terhadap mutu papan partikel yang dibuat dari limbah padat hasil pengolahan Gracilaria sp. dan polietilen. Pada penelitian ini limbah padat hasil pengolahan Gracilaria sp. dicampur secara homogen pada suhu ruang dengan bahan perekat polietilen dengan perbandingan berat $1: 1$, dan ditambahkan maleat anhidrida dengan konsentrasi $0,6,9$, dan $12 \% \mathrm{~b} / \mathrm{b}$. Pembuatan papan partikel dilakukan dengan teknik pengempaan panas pada cetakan $30 \times 30 \times 4 \mathrm{~cm}^{3}$. Pengempaan dilakukan pada tekanan $9 \mathrm{~kg} / \mathrm{cm}^{2}$, suhu $150^{\circ} \mathrm{C}$, dengan lama waktu pengempaan 7 menit. Hasil penelitian menunjukkan bahwa penambahan maleat anhidrida sebagai compatibilizer pada pembuatan papan partikel dari limbah padat pengolahan Gracilaria sp. dan polietilen berpengaruh pada meningkatnya kadar air, daya serap air dan pengembangan tebal serta berpengaruh pada menurunnya modulus patah (MOR) dan modulus elastisitas papan. Pada penelitian ini pembuatan papan partikel dari limbah Gracilaria sp. dan polietilen dapat menghasilkan papan dengan sifat fisik dan mekanis yang sesuai standar JIS A5908 kecuali pada nilai modulus elastisitasnya.
\end{abstract}

KATAKUNCl: $\quad$ maleat anhidrida, papan partikel, limbah padat, Gracilaria sp.

ABSTRACT: Effect of maleic anhydride concentration on the characteristics of particle board made from solid waste of Gracilaria sp. extraction with polyetilene as binder. By: Diini Fithriani, Jamal Basmal and Bagus Sediadi Bandol Utomo

\begin{abstract}
The purpose of this research was to investigate the effect of maleic anhydride to the particle board made from solid waste of Gracilaria sp. extraction and polyethylene. In this research, solid waste from Gracilaria sp. extraction was mixed until homogen with a binder of polyethylene/PE, at a ratio of $1: 1$ by weight and added with maleic anhydride at concentration 0, 6, 9 and $12 \%$ by weight. Particle board was made by applying heat-pressing technique in a square templates of 30 $\times 30 \times 4 \mathrm{~cm}^{3}$. The pressure applied was $9 \mathrm{~kg} / \mathrm{cm}^{2}$ at $150^{\circ} \mathrm{C}$ for 7 minutes. The result showed that the addition of maleic anhydride as compatibilizer in the production of particle board made from Gracilaria sp. and polyethylene increased the water content, water absorption and swelling of its thickness and descreased the Modulus of Rupture (MOR) and Modulus of Elasticity (MOE). In this research particle board made from solid waste of Gracilaria sp. extraction and polyethylene resulting particle boards that have physical and mechanical characteristic of particle board that suitable with JIS A-5908 standard except modulus of elasticity.
\end{abstract}

KEYWORDS: maleic anhydride, particle board, solid waste, Gracilaria sp.

\section{PENDAHULUAN}

Limbah padat hasil pengolahan rumput laut Gracilaria sp. merupakan biomassa yang memiliki potensi untuk dikembangkan menjadi papan partikel (Fithriani et al., 2006; Sedayu et al., 2008). Papan partikel adalah komposit berbahan dasar kayu yang terdiri dari berbagai bentuk dan ukuran partikel dari bahan lignoselulosa yang diikat dengan perekat dan dikempa pada tekanan tertentu dan pada suhu tinggi (Hashim et al., 2011). Limbah rumput laut Gracilaria sp. memiliki karakteristik yang diperlukan sebagai bahan baku papan partikel. Limbah ini mengandung lignoselulosa, yang merupakan syarat utama pada pembuatan papan partikel. Menurut Kim et al. (2007) limbah pengolahan agar dari rumput laut masih mengandung selulosa sebesar $15-25 \%$. Selain itu limbah Gracilaria sp. ini juga memiliki ketersediaan yang tinggi, pada tahun 2008 limbah dari pengolahan rumput laut di Indonesia sudah mencapai 1.682.542 ton (Harvey, 2009).

Pemanfaatan limbah pengolahan rumput laut Gracilaria sp. pada pembuatan papan partikel telah dilakukan dengan menggunakan perekat termoplastik polipropilen (Fithriani et al., 2006) dan perekat termoplastik polietilen (Sedayu et al., 2008).

Peneliti pada Balai Besar Penelitian dan Pengembangan Pengolahan Produk dan Bioteknologi Kelautan dan Perikanan, Balitbang KP, KKP; JI. KS. Tubun Petamburan VI, Jakarta Pusat; E-mail:diini_fithriani@yahoo.com 
Keunggulan utama papan partikel kombinasi limbah rumput laut dan perekat termoplastik adalah kestabilan dimensi yang tinggi, yang dicirikan dengan nilai daya serap air dan pengembangan tebal yang rendah (Fithriani et al., 2006; Sedayu et al., 2008). Sedangkan kelemahan papan partikel dari limbah Gracilaria sp. adalah rendahnya nilai kerapatan dan modulus elastisitas (MOE) (Fithriani et al., 2006) serta rendahnya nilai modulus patah (MOR) juga modulus elastisitas (MOE) (Sedayu et al., 2008).

Dalam rangka menghasilkan papan partikel yang sesuai dengan standar komersial papan, maka penelitian perbaikan mutu papan partikel perlu terus dilakukan. Dalam penelitian ini digunakan polietilen dengan komposisi per berat 50\%. Penggunaan polietilen didasarkan pada penelitian Massijaya et al. (2000) yang menyatakan bahwa secara umum polietilen memberikan hasil yang lebih baik dibandingkan kedua jenis plastik lainnya yaitu polipropilen dan polistiren. Sedangkan Nagaich (1996) menyatakan dalam rangka menghasilkan papan dengan mutu yang baik adalah perlu untuk menambahkan sejumlah besar plastik/perekat termoplastik dalam formula sebesar $50 \%$ atau lebih besar.

Rendahnya kerapatan, MOE, dan modulus patah papan partikel dari limbah rumput laut dengan perekat termoplastik, dapat disebabkan karena pencampuran limbah rumput laut dan perekat termoplastik. Limbah rumput laut dan perekat termoplastik merupakan 2 bahan yang berbeda. Limbah rumput laut bersifat hidrofilik, sedangkan perekat termoplastik bersifat hidrofobik. Pencampuran kedua bahan tersebut dapat menghasilkan interfacial adhesion yang rendah. Pendekatan yang dapat dilakukan untuk meningkatkan kompatibilitas antara lignoselusa dan perekat termoplastik, adalah dengan menambah berbagai macam compatibilizer (Mahbelrg et al., 2001). Maleat anhidrida adalah compatibilizer yang paling populer diantara semua jenis anhidrida. Menurut Iswanto (2005) maleat anhidrida dapat diberikan sebagai compatibilizer pada material polimer seperti polipropilen, polietilene, dan acrylonitrile butadine styrene copolymer. Penggunaan maleat anhidrida sebagai compatibilitas telah dilakukan pada beberapa pembuatan komposit dan berefek positif seperti komposit berbahan baku kayu-PP dan PF (Mahbelrg et al., 2001), komposit berbahan baku pinus-polymeric diphenylmethane diisocyanate (Ruffing et al., 2009) dan komposit berbahan baku serbuk batang kelapa sawit-PP (Harisandi, 2010). Tujuan penelitian ini adalah untuk mempelajari pengaruh maleat anhidrida terhadap mutu papan partikel yang dibuat dari limbah padat Gracilaria sp. dan polietilen.

\section{BAHAN DAN METODE}

\section{Bahan}

Bahan baku yang digunakan dalam penelitian ini adalah limbah Gracilaria sp. yang berbentuk padat, yang diperoleh dari penampungan limbah industri pengolahan Gracilaria sp. di Pasar Kemis, Tangerang, maleat anhidrida dan tepung polietilen. Alat yang digunakan meliputi timbangan, alat pres hidrolik, dan alat-alat untuk analisis produk.

\section{Metode}

Dalam penelitian ini, papan partikel dibuat dengan pencampuran bahan baku dengan perekat dan maleat anhidrida pada berbagai konsentrasi, dan dikempa pada tekanan tertentu pada suhu tinggi. Papan partikel ini kemudian diuji sifat fisik dan mekaniknya dan dibandingkan dengan JIS A5908 (JSA, 1994) dan SNI 03 2105-1996 (BSN,1996).

\section{Pembuatan papan partikel}

Bahan baku disiapkan dengan menjemur limbah padat dari industri pengolahan Gracilaria sp. di bawah sinar matahari selama 2-3 hari hingga mencapai kadar air $5 \%$. Limbah yang telah kering kemudian digiling menggunakan hammer mill hingga berbentuk tepung dengan ukuran partikel 26 mesh. Setelah itu, sebanyak $150 \mathrm{~g}$ tepung limbah dicampur dengan 150 $\mathrm{g}$ polietilen dan ditambahkan maleat anhidrida dengan konsentrasi $0,6,9$, dan $12 \%$ b/b. Konsentrasi maleat anhidrida ini mengacu pada Delita (2002) yang menggunakan serbuk gergaji kayu sengon (Paraserianthes falcataria) dan limbah plastik polipropilen sebagai perekat. Pencampuran dilakukan dengan memasukkan bahan ke dalam kantung plastik dan dikocok hingga homogen. Bahan yang telah tercampur dengan homogen dimasukkan ke alat pencetak papan partikel berukuran $p \times \mid \times t=30 \mathrm{~cm} \times$ $30 \mathrm{~cm} \times 4 \mathrm{~mm}$, kemudian dilakukan pengempaan dengan tekanan $9 \mathrm{~kg} / \mathrm{cm}^{2}$ pada suhu $150^{\circ} \mathrm{C}$ selama 7 menit.

\section{Pengujian sifat fisik dan mekanik}

Pengujian sifat fisik dan mekanik papan partikel meliputi kerapatan, kadar air, daya serap air, pengembangan linear pada 2 jam dan 24 jam, pengembangan tebal pada 2 jam dan 24 jam, modulus patah (MOR), modulus elastisitas (MOE), dan kekuatan rekat internal. Pengujian dilakukan berdasarkan standar JIS A5908 (JSA, 1994). Untuk mengetahui pengaruh waktu pengempaan terhadap sifat fisik mekanik papan dilakukan analisis sidik ragam dengan rancangan acak lengkap (Steel \& 
Torrie, 1993) dengan 3 kali ulangan. Sifat fisik dan mekanik papan partikel merupakan parameter yang cukup baik untuk menduga kualitas papan partikel yang dihasilkan. JIS A5908 (JSA,1994) dan SNI 03 2105-1996 (BSN,1996) menetapkan persyaratan sifat fisik dan mekanik papan partikel yang harus dipenuhi, seperti terlihat pada Tabel 1.

\section{HASIL DAN BAHASAN}

\section{Sifat Fisik Papan Partikel}

\section{Kerapatan}

Kerapatan papan partikel yang dihasilkan dalam penelitian ini adalah berkisar antara $0,74-0,9 \mathrm{~g} / \mathrm{cm}^{3}$ (Gambar 1). Kerapatan tertinggi diperoleh dari perlakuan konsentrasi maleat anhidrida $12 \%$ dan kerapatan terendah diperoleh dari perlakuan kontrol. Kerapatan didefinisikan sebagai massa atau berat per satuan volume (Haygreen \& Bowyer, 1989).

JIS A5908 (JSA, 1994) dan SNI 03 2105-1996 (BSN1996) mensyaratkan kerapatan papan partikel berkisar antara 0,4-0,9 g/ $\mathrm{cm}^{3}$ dan dikategorikan papan berkerapatan sedang. Berdasarkan JIS A5908 (JSA, 1994) dan SNI 03 2105-1996 (BSN,1996) penelitian ini menghasilkan papan partikel yang dapat dikategorikan sebagai papan partikel berkerapatan sedang. Dibandingkan hasil penelitian sebelumnya pada pembuatan papan partikel dari limbah rumput laut dengan perekat polipropilen dalam komposisi yang sama (Fithriani et al., 2006), kerapatan yang diperoleh semua perlakuan pada penelitian ini sudah jauh lebih baik dibandingkan nilai kerapatan yang diperoleh sebelumnya yang hanya berkisar antar 0,08-0,09 g/ $\mathrm{cm}^{3}$.

Tabel 1. Sifat fisik dan mekanik papan partikel menurut standar JIS A-5908 dan SNI 03 2105-1996

Table 1. Physical and mechanical characteristic of particle board according to standard JIS A-5908 and SNI 03 2105-1996

\begin{tabular}{|c|c|c|}
\hline \multirow{2}{*}{$\begin{array}{l}\text { Sifat Papan Partikel/ } \\
\text { Particle Board Characteristic }\end{array}$} & \multicolumn{2}{|c|}{ Persyaratan Nilai/Value Standard } \\
\hline & (JIS A-5908) & (SNI 03 2105-1996) \\
\hline Kerapatan/Density $\left(\mathrm{g} / \mathrm{cm}^{3}\right)$ & $0.4-0.9$ & $0.4-0.9$ \\
\hline Kadar air/Moisture content (\%) & $5-13$ & $<14$ \\
\hline Daya serap air/Moisture absorption (\%) & & $20-75$ \\
\hline Pengembangan tebal/Swelling (\%) & Maksimal 12 & \\
\hline $\begin{array}{l}\text { Modulus patah/Modulus of rupture (MOR) }\left(\mathrm{kg} / \mathrm{cm}^{2}\right) \\
\text { Tipe } 8 / \text { Tipe } 100\end{array}$ & Minimal 82 & Minimal 80 \\
\hline $\begin{array}{l}\text { Modulus elastisitas/Modulus of elasticity (MOE) } \\
\left(\mathrm{kg} / \mathrm{cm}^{2}\right) \text { Tipe } 8 / \text { Tipe } 100\end{array}$ & Minimal 20400 & Minimal 15000 \\
\hline $\begin{array}{l}\text { Kekuatan rekat internal/Internal bond }\left(\mathrm{kg} / \mathrm{cm}^{2}\right) \\
\text { Tipe } 8 / \text { Tipe } 100\end{array}$ & Minimal 1.5 & Minimal 1.5 \\
\hline
\end{tabular}

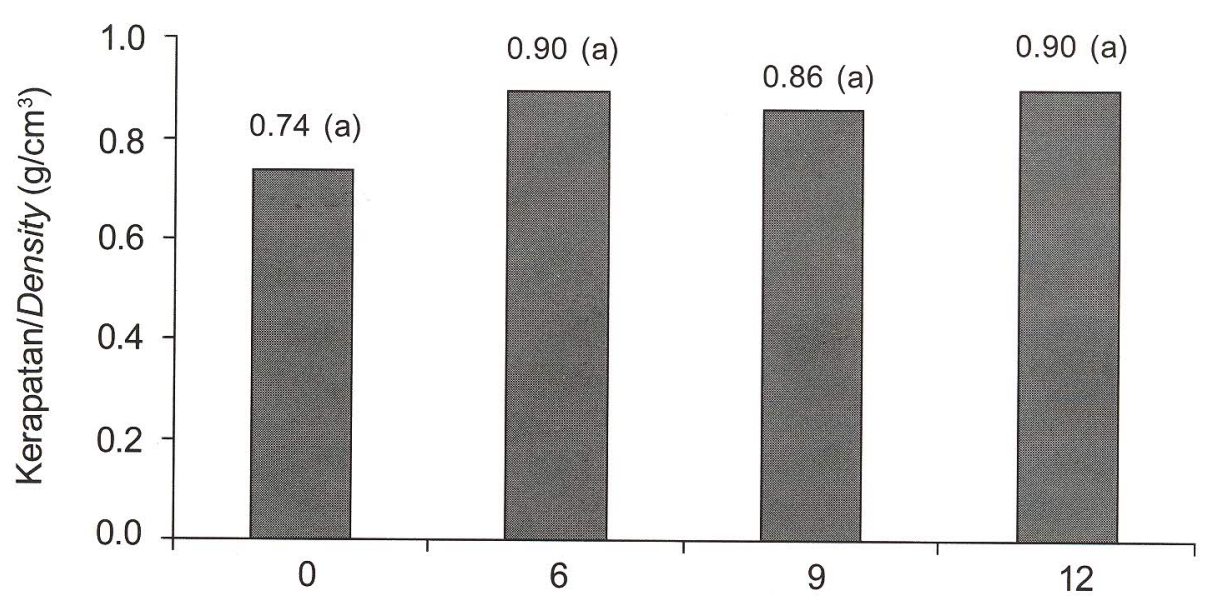

Konsentrasi Maleat Anhidrida/Maleic Anhydride Concentration (\%)

Gambar 1. Pengaruh konsentrasi maleat anhidrida terhadap kerapatan papan partikel.

Figure 1. Effect concentration of maleic anhydride between density particle board. 
Dari penelitian ini diperoleh hasil bahwa tidak ada perbedaan nyata pada kerapatan papan partikel yang ditunjukkan oleh hasil analisis sidik ragam yang tidak berbeda nyata $(p>0,05)$. Hal ini menunjukkan bahwa penambahan maleat anhidrida tidak berpengaruh pada kerapatan papan partikel. Salah satu faktor yang berpengaruh terhadap kerapatan papan adalah proses homogenisasi serbuk limbah, maleat anhidrida, dan polietilen yang kemungkinan besar telah merata karena menurut Haygreen \& Bowyer (1989) distribusi partikel penyusun papan yang merata, secara vertikal maupun horizontal menghasilkan kerapatan yang baik.

\section{Kadar air}

Kadar air papan partikel yang dihasilkan dalam penelitian ini adalah berkisar antara $2,7-5,7 \%$ (Gambar 2). Kadar air merupakan sifat fisik papan partikel yang menunjukkan kandungan air papan partikel dalam keadaan kesetimbangan dengan lingkungan sekitarnya terutama kelembaban udara.

JIS A5908 (JSA, 1994) menetapkan nilai kadar air untuk papan partikel antara 5-13\%, sedangkan SNI 03-2105-1996 (BSN,1996) mensyaratkan nilai kadar air untuk papan partikel $<12 \%$. Pada pengukuran kadar air seperti ditunjukkan pada Gambar 2, diketahui bahwa kadar air pada konsentrasi maleat anhidrida 0 dan $6 \%$ tidak memenuhi standar JIS A5908 sedangkan kadar air pada konsentrasi maleat anhidrida 9 dan $12 \%$ telah masuk dalam standar JIS A5908. Namun jika merujuk pada standar SNI 03 2105-1996 (BSN,1996) nilai kadar air semua papan partikel yang dihasilkan telah memenuhi standar yang disyaratkan.

Dari penelitian ini diperoleh hasil bahwa terdapat perbedaan nyata pada kadar air papan partikel, yang ditunjukkan oleh hasil analisis sidik ragam yang berbeda nyata $(p<0,05)$. Hasil analisis statistik lanjutan yaitu uji Duncan pada $\alpha=0,05$ menunjukkan bahwa kadar air papan partikel dengan maleat anhidrida $0 \%$ berbeda dengan papan partikel dengan maleat anhidrida 6,9 , dan $12 \%$ sedangkan kadar air papan partikel pada konsentrasi 6,9 , dan $12 \%$ tidak berbeda nyata. Dari hasil penelitian diketahui bahwa kadar air papan partikel meningkat setelah diberi maleat anhidrida. Menurut Delita (2002) jika maleat anhidrida tidak berikatan dengan group $\mathrm{OH}$ dari serbuk limbah maka ikatan silang ester tidak terbentuk sehingga kemampuan papan menarik dan menahan air meningkat.

\section{Daya serap air}

Daya serap air papan partikel yang dihasilkan dalam penelitian ini adalah berkisar antara 8,5-13,9\% (Gambar 3). Daya serap air adalah salah satu karakteristik yang penting dari komposit campuran bahan berlignoselulosa dan perekat termoplastik dalam hubungannya dengan lingkungan terkait aplikasi akhir dari produk (Ashori \& Nourbakhsh, 2009).

JIS A5908 (JSA, 1994) tidak menetapkan standar untuk sifat daya serap air sedangkan menurut standar SNI 03 2105-1996 (BSN,1996) nilai penyerapan air untuk papan partikel berkerapatan sedang adalah 20$75 \%$.

Dari penelitian ini diperoleh hasil bahwa terdapat perbedaan nyata pada daya serap air papan partikel, yang ditunjukkan oleh hasil analisis sidik ragam pada daya serap air papan partikel yang berbeda nyata $(p<0,05)$. Hasil analisis statistik lanjutan yaitu uji Duncan pada $\alpha=0,05$ menunjukkan bahwa perlakuan 6,9 , dan $12 \%$ tidak berbeda nyata namun berbeda nyata terhadap perlakuan kontrol $(0 \%)$.

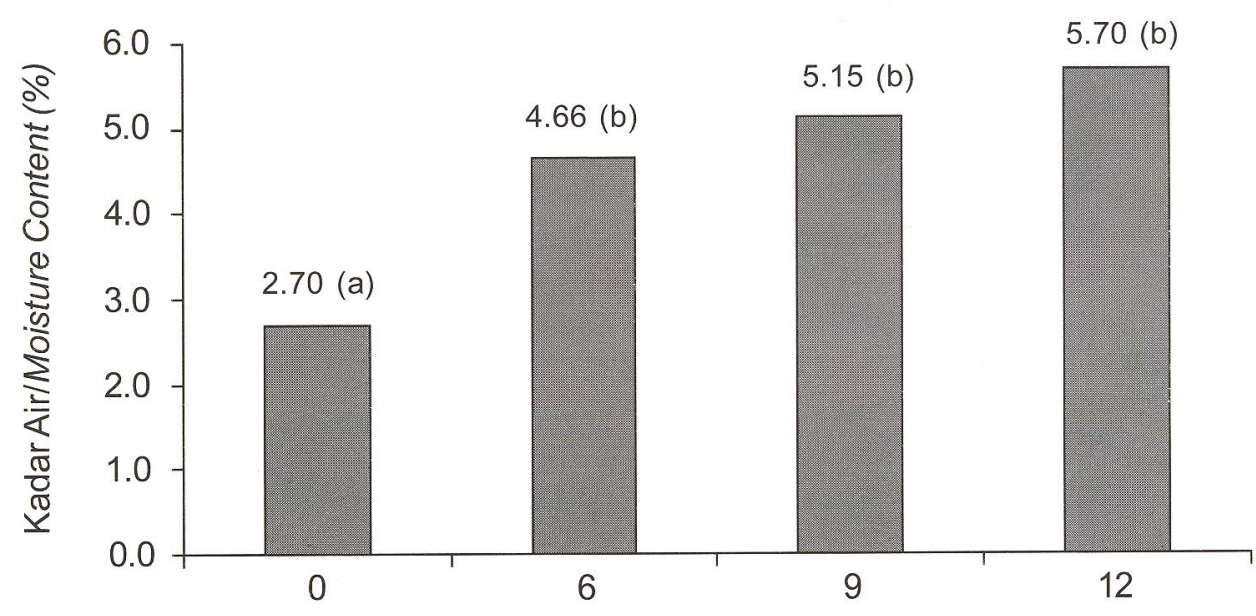

Konsentrasi Maleat Anhidrida/Maleic Anhydride Concentration (\%)

Gambar 2. Pengaruh konsentrasi maleat anhidrida terhadap kadar air papan partikel Figure 2. Effect concentration of maleic anhydride between moisture content particle board. 


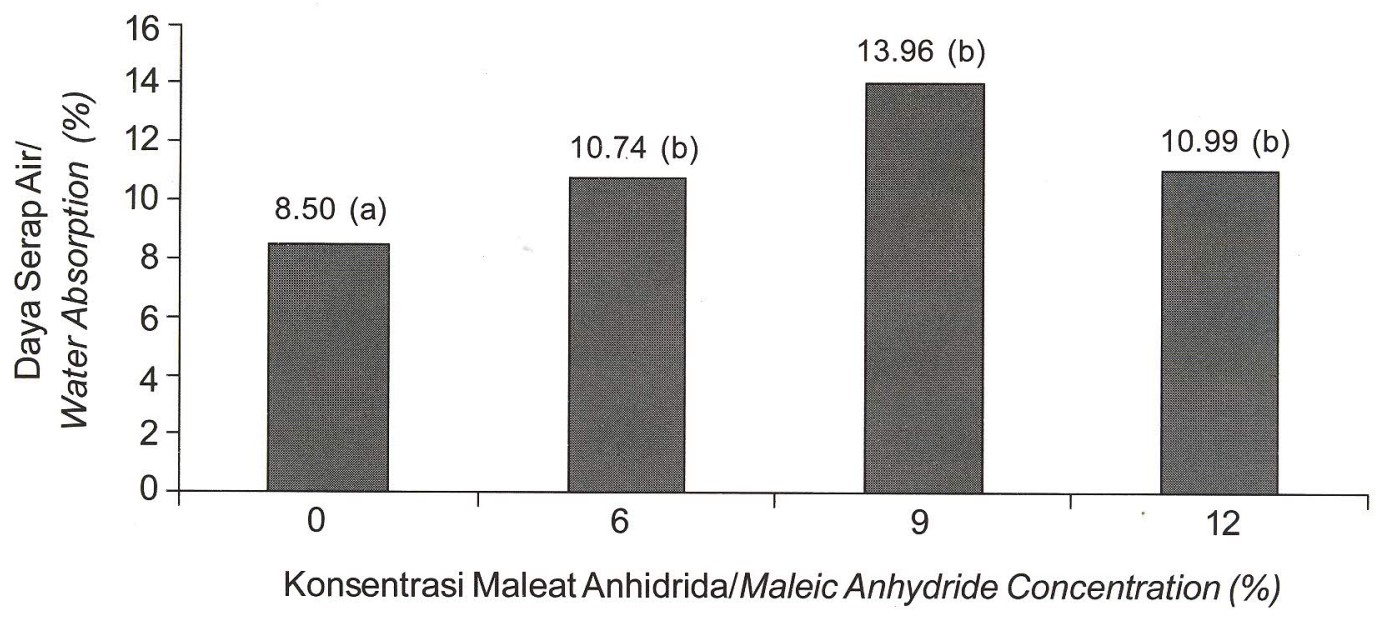

Gambar 3. Pengaruh konsentrasi maleat anhidrida terhadap daya serap air papan partikel Figure 3. Effect concentration of maleic anhydride between water absorption particle board.

Secara umum dari hasil pengujian diketahui bahwa daya serap air meningkat setelah ditambah maleat anhidrida. Penambahan daya serap air menunjukkan bahwa kestabilan dimensi papan partikel berkurang setelah diberi maleat anhidrida. Hal ini berbeda dengan penelitian $\mathrm{Li}(2010)$ yang menyatakan bahwa maleat anhidrida dapat meningkatkan kestabilan dimensi dari kayu karena maleat anhidrida mampu berikatan dengan grup hidroksil dari kayu/bahan berlignoselusa yang bersifat menarik air.

Meningkatnya daya serap air menunjukkan bahwa maleat anhidrida tidak bereaksi dengan limbah padat rumput laut yang digunakan karena seharusnya menurut Mahbelrg et al. (2001) anhidrida dapat menurunkan gugus $\mathrm{OH}$ yang bersifat menarik air, pada bahan kayu (bahan yang mengandung lignoselulosa) dengan membentuk ester, hal ini menyebabkan kemampuan menarik air akan menurun.

Tidak bereaksinya maleat anhidrida dengan limbah padat rumput laut kemungkinan disebabkan karena komposisi dari bahan baku yang mengandung tanah diatom, dimana hal ini dapat menghalangi terjadinya proses kimia antara maleat anhidrida selulosa yang terkandung pada limbah. Secara umum dari hasil pengujian, diketahui bahwa daya serap air dari papan partikel yang dihasilkan cukup rendah. Rendahnya daya serap air ini menunjukkan bahwa kestabilan dimensi papan cukup baik, meskipun kestabilannya sedikit menurun ketika diberi maleat anhidrida. Rendahnya daya serap air dalam penelitian ini dapat pula disebabkan karena peran dari polietilen yang bersifat hidrofobik. Menurut Mudjijanto (2000) Kemampuan menyerap air pada polietilen sangat rendah yaitu sebesar $0,04 \%$ dalam perendaman 24 jam.

\section{Pengembangan tebal}

Pengembangan tebal papan partikel yang dihasilkan dalam penelitian ini adalah berkisar antara $1,2-1,5 \%$ (Gambar 4). Hasil analisis sidik ragam

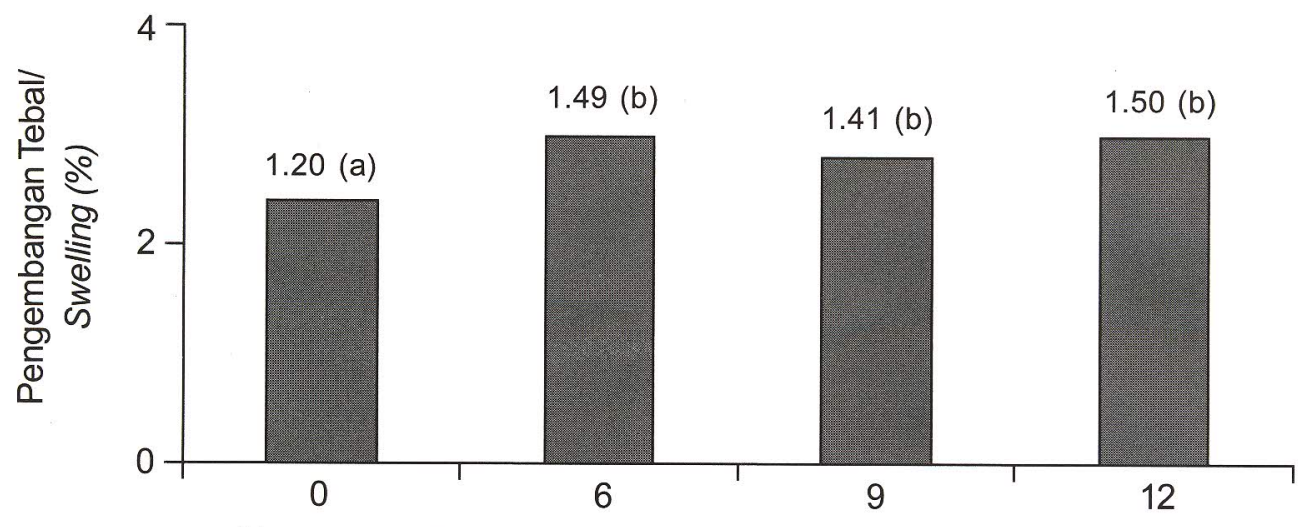

Konsentrasi Maleat Anhidrida/Maleic Anhydride Concentration (\%)

Gambar 4. Pengaruh konsentrasi maleat anhidrida terhadap pengembangan tebal papan partikel. Figure 4. Effect concentration of maleic anhydride between thickeness swelling particle board. 
menunjukkan bahwa terdapat perbedaan yang nyata $(p<0,05)$ pada pengembangan tebal papan. Hasil analisis statistik lanjutan yaitu uji Duncan pada $\alpha=$ 0,05 menunjukkan bahwa perlakuan 6,9 , dan $12 \%$ tidak berbeda nyata namun berbeda nyata terhadap perlakuan kontrol (0\%).

Sifat pengembangan tebal merupakan sifat fisik yang akan menentukan apakah suatu papan partikel dapat digunakan untuk keperluan eksterior atau interior (Massijaya et al., 2000). JIS A5908 (JSA, 1994) menetapkan nilai pengembangan tebal untuk papan partikel maksimum $12 \%$. Jika dibandingkan dengan standar JIS A5908 (JSA, 1994) pengembangan tebal papan partikel dalam penelitian ini sangat rendah, hal ini disebabkan karena penggunaan polietilen yang bersifat hidrofobik yang cukup besar yaitu sebanyak $50 \%$. Rendahnya pengembangan tebal di lain pihak secara positif menunjukkan kestabilan dimensi yang tinggi. Kestabilan dimensi yang tinggi ini dapat menjadi acuan penggunaan papan partikel dari limbah Gracilaria sp. dan polietilen sebagai sebagai material interior maupun eksterior.

Pada penelitian ini penambahan maleat anhidrida berpengaruh dalam meningkatkan pengembangan tebal papan partikel atau dengan kata lain menurunkan kestabilan dimensi papan. Meningkatnya pengembangan tebal papan ini disebabkan oleh meningkatnya daya serap air setelah diberi maleat anhidrida. Menurut Ashori \& Sheshmani (2010) lemahnya resistensi terhadap penyerapan air dari bahan berlignoselulosa terutama disebabkan karena kehadiran group polar yang menarik molekul air melalui ikatan hidrogen. Fenomena ini menyebabkan kandungan air meningkat dalam dinding sel fiber dan juga dalam ikatan fiber dan matrik. Hal ini yang menyebabkan perubahan dimensi komposit berbahan dasar selulosa terutama pada ketebalan.

\section{Sifat Mekanik Papan Partikel}

\section{Kekuatan rekat internal}

Kekuatan rekat internal papan partikel yang dihasilkan dalam penelitian ini adalah berkisar antara $7,11-8,16 \mathrm{~kg} / \mathrm{cm} 2$ (Gambar 5). Kekuatan rekat internal adalah ukuran tunggal terbaik tentang kualitas pembuatan suatu papan karena menunjukkan kekuatan ikatan antara partikel-partikel (Massijaya et al., 2000).

Secara umum kekuatan rekat internal papan partikel pada penelitian ini memenuhi persyaratan JIS A5908 (JSA,1994) dan standar SNI 03 2105-1996 (BSN,1996). Dari penelitian ini diperoleh hasil bahwa tidak terdapat perbedaan nyata kekuatan rekat internal papan partikel, yang ditunjukkan oleh hasil analisis sidik ragam pada kekuatan rekat internal papan partikel yang tidak berbeda nyata $(p>0,05)$. Kekuatan rekat internal papan yang tidak berbeda nyata menunjukkan bahwa tidak ada reaksi yang terjadi ketika maleat anhidrida ditambahkan pada limbah rumput laut. Kekuatan papan partikel pada dasarnya ditentukan oleh kekuatan ikatan antar partikel dan kekuatan masing-masing partikel itu sendiri. Pemakaian partikel halus akan meningkatkan luas areal permukaan per satuan berat yang menyebabkan penggunaan perekat menjadi kurang efisien, serta lebih banyaknya individu-individu serat yang mengalami kerusakan, sehingga akan menghasilkan lembaran dengan kekuatan yang rendah serta merosotnya stabilitas dimensi (Lehman, 1974 dalam Djalal, 1984).

\section{Modulus elastisitas (MOE)}

Modulus elastisitas papan partikel yang dihasilkan dalam penelitian ini berkisar antara $3.505-6.326 \mathrm{~kg} /$ $\mathrm{cm}^{2}$ (Gambar 6). Modulus elastisitas merupakan

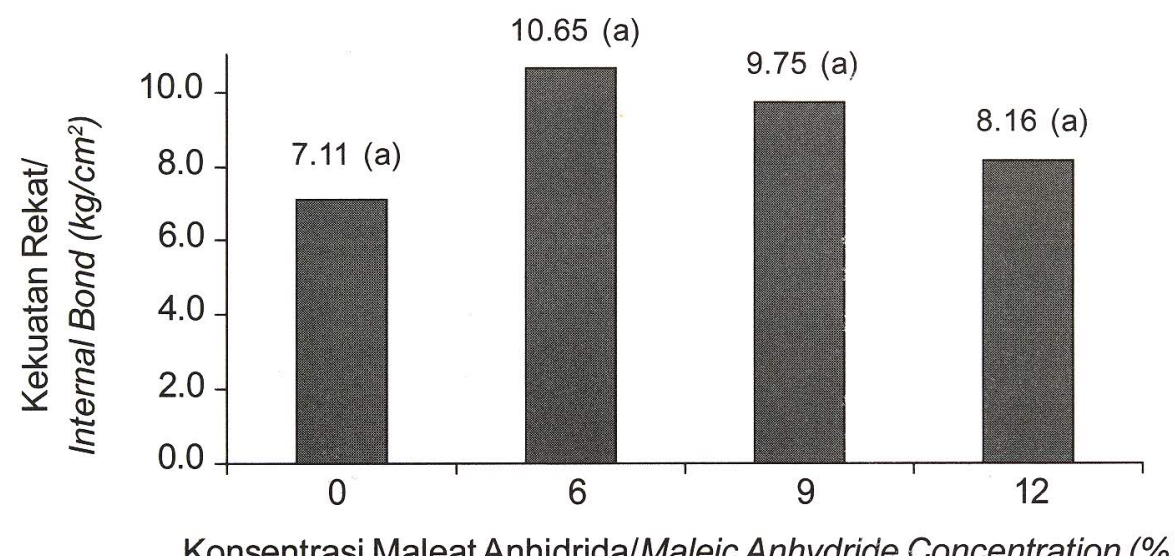

Gambar 5. Pengaruh konsentrasi maleat anhidrida terhadap kekuatan rekat internal papan partikel.

Figure 5. Effect concentration of maleic anhydride between internal bond particle board. 


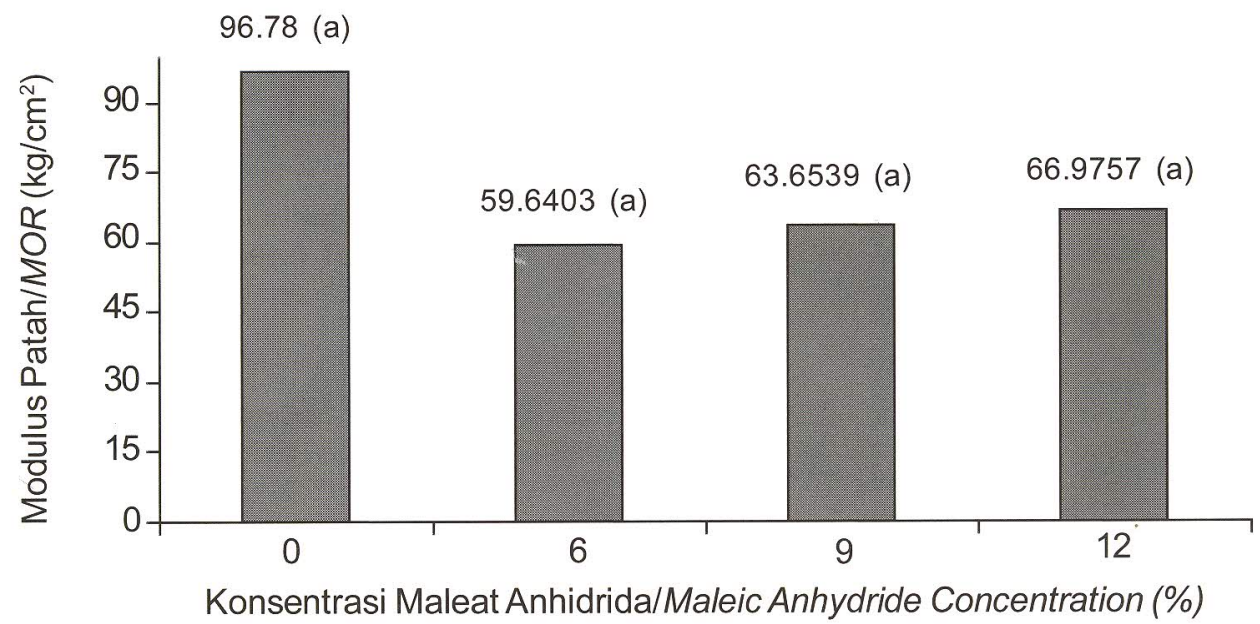

Gambar 7. Pengaruh konsentrasi maleat anhidrida terhadap modulus patah papan partikel.

Figure 7. Effect concentration of maleic anhydride between modulus of rupture particle board.

papan partikel masing-masing minimum sebesar 82 $\mathrm{kg} / \mathrm{cm}^{2}$ dan $80 \mathrm{~kg} / \mathrm{cm}^{2}$, sedangkan hasil percobaan menunjukkan, nilai MOR papan partikel dengan konsentrasi 6 , 9, dan 12\% masih lebih rendah dibandingkan dengan nilai yang disyaratkan. Hal ini diduga karena tidak terjadinya ikatan spesifik antara partikel limbah rumput laut dengan partikel plastik (Perlson \& Schababerle, 1992). Rendahnya nilai MOR papan partikel konsentrasi 6, 9, dan $12 \%$ mengindikasikan bahwa ketahanan papan menahan beban rendah sehingga penggunaannya menjadi terbatas sebagai material non kontruksi seperti daun pintu, kusen, atau jendela dan tidak dapat diperuntukkan sebagai material kontruksi.

\section{KESIMPULAN}

1. Dalam pembuatan papan partikel dari limbah pengolahan Gracilaria sp. dan polietilen semua perlakuan menghasilkan papan dengan stabilitas dimensi yang tinggi yang ditunjukkan dengan kadar air, daya serap air, dan pengembangan tebal yang rendah sehingga papan dapat diperuntukkan baik sebagai material eksterior maupun interior.

2. Pembuatan papan partikel dari limbah Gracilaria sp. dan polietilen dapat menghasilkan papan dengan mutu yang cukup baik yang sesuai standar JIS A5908 (JSA, 1994) yang merupakan standar papan komersial kecuali pada modulus elastisitasnya masih rendah.

3. Penambahan maleat anhidrida sebagai compatibilizer pada pembuatan papan partikel dari limbah Gracilaria sp. dan polietilen adalah tidak memberikan pengaruh terhadap modulus elastisitas, kerapatan, dan internal bond dan berpengaruh negatif terhadap kadar air, daya serap air, pengembangan tebal, dan modulus patah.

\section{SARAN}

Berdasarkan hasil penelitian penulis menyarankan untuk memperbaiki mutu produk papan partikel terutama modulus elastisitas dengan mencoba menggunakan berbagai compatibilizer lain yang tersedia seperti Glicydilmethacrylate dan Hydroxiethilmethacrylate.

\section{DAFTAR PUSTAKA}

Abdurachman dan Hadjib, N. 2006. Pemanfaatan kayu hutan rakyat untuk komponen bangunan. Prosiding Seminar Hasil Litbang Hasil Hutan 2006. p. 130148.

Japanese Standard Association (JSA). 1994. Particleboards. JIS A 5908-1994. Tokyo.

Badan Standarisasi Nasional (BSN). 1996. SNI 032105-1996. Mutu Papan Partikel. Badan Standardisasi Nasional, Jakarta.

Ashori, A. and Nourbakhsh, A. 2009. Effects of nanoclay as a reinforcement filler on the physical and mechanical properties of wood based composite. Composite Materials. 43(18): 1869-1875.

Ashori, A. and Sheshmani, S. 2010. Hybrid composites made from recycled materials: Moisture absorption and thickness swelling behavior. Bioresource Technology. 101(12): 4717-4729.

Delita, M. 2002. Peningkatan Mutu Papan Partikel dari Limbah Serbuk Gergaji Kayu Sengon (Paraserianthes falcataria) dan Limbah Plastik Polipropilen : Peranan Maleat Anhidrida sebagai Compatilibizer. Skripsi. Fakultas Kehutanan, Institut Pertanian Bogor.

Djalal, M. 1984. Peranan Kerapatan Kayu dan Kerapatan Lembaran dalam Usaha Perbaikan Sifat-Sifat Mekanik dan Stabilitas Dimensi Papan Partikel dari Beberapa Jenis Kayu dan Campurannya. Disertasi. Sekolah Pascasarjana, Institut Pertanian Bogor, Bogor. 
Fithriani, D., Nugroho, T., dan Basmal, J. 2006. Pengaruh waktu pengempaan terhadap karakteristik papan partikel dari limbah padat pengolahan Gracilaria sp. Jurnal Pascapanen dan Bioteknologi Kelautan dan Perikanan. 1(2): 125-134.

Harisandi, H. 2010. Pembuatan Papan Partikel dari Serbuk Batang Kelapa Sawit Menggunakan Perekatpolipropilena Difungsionalisasi dengan Maleat Anhidrat. Skripsi .Universitas Sumatera Utara Medan.

Harvey, F. 2009. Produksi Bioetanol dari Limbah Karagenan. Skripsi. Fakultas Perikanan dan IImu Kelautan, Insitut Pertanian Bogor, Bogor.

Hashim, R., Aidawati, W.N., Nadhari, W., Sulaiman, O. Kawamura, F., Hiziroglu, S., Sato, M., Sugimoto, T, Seng, T.G., and Tanaka, R. 2011.Characterization of raw materials and manufactured binderless particleboard from oil palm biomass. Materials and Design. 32: 246-254.

Haygreen, J.G. dan Bowyer. J.L. 1989. Hasil Hutan dan IImu Kayu: Suatu Pengantar. Diterjemahkan oleh Sutjipto A.Hadikusumo Gadjah Mada University Press, Yogyakarta. p. 275-284

Iswanto, A.H. 2005. Polimer komposit. Jurusan Kehutanan. Fakultas Pertanian. Universitas Sumatera Utara. repository.usu.ac.id/bitstream/ 123456789/.../hutan-apri\%20heri.pdf. Diakses pada tanggal 3 Mei 2011.

Kim, G.S., Myung, K.S., Kim, Y.J., Oh, K.K., Kim, J.S., Ryu, H.J., and Kim, K.H. 2007. Method of Producing Biofuel Using Sea Algae. World Intelectual Property Organization, Seoul.

Li, X.G., Hu, N., and Wu,Y.Q. 2010. Study on the processing technology of bamboo mat/bamboo particle composite board. Advanced Materials Research. 150-151: 1433-1437.

Mahlberg, R., Paajanen, L., Nurmi, A., Kivistö, A., Koskela, K., and Rowell, R.M. 2001. Effect of chemical modification of wood on the mechanical and adhesion properties of wood fiber/polypropylene fiber and polypropylene/veneer composites. Holz als Rohun workstuff. 59: 319-326.

Massijaya, M.Y., Hadi, Y.S., Tambunan, B., Bakar, E.S. dan Subari. 2000. Penggunaan limbah plastik sebagai komponen bahan baku papan partikel. Jurnal Teknologi Hasil Hutan. 13(2): 21-22.

Mudjijanto. 2000. Determinasi komposisi Optimum Campuran Partikel Kayu dan Plastik pada Papan Komposit. Skripsi. Fakultas Kehutanan, Institut Pertanian Bogor, Bogor.

Nagaich. 1996. Vinyl based cellulose reinforced. United States Patent 6011091 diakses dari composite. http:/ /www. freepatentsonline.com/6011091.html. Diakses pada bulan Mei 2011.

Perlson, B.D. and Schababerle, C.C. 1992. Polyolefins. Plastic Recycling, Products and Process. Hansher Publishers.

Ruffing, T.C., Brown, N.R., Cionni, V., Takah, J.S., and McCracken,T. 2009. Effect of maleat anhidrida polypropylene copolymer addition on the physical and mechanical properties of polymeric diphenylmethane diisocyanate-bonded oriented strand board panels. Forest Product. 59: 1-10.

Sedayu, B.B., Widiantio, T.N., Basmal, J., dan Utomo, B.S.B. 2008. Pemanfaatan limbah padat pengolahan rumput laut Gracilaria sp. untuk pembuatan papan partikel. Jurnal Pascapanen dan Bioteknologi Kelautan dan Perikanan. 3(1): 1-10.

Steel, R.G.D. and Torrie, J.H. 1993. Prinsip dan Prosedur Statistik. Terjemahan dari Principles and Procedures of Statistic, oleh Bambang Sumantri. Gramedia Pustaka Utama, Jakarta.

Talavera, F.J.F., Guzm an, J.A.S., Richter, H.G., Duẽnas, R.S., and Quitarte, J.R. 2007. Effect of production variables on bending properties, water absorption and thickness swelling of bagasse/plastic composite boards. Industrial Crops and Products. 26: 1-7.

Warsono. 2008. Tinjauan Kuat Lentur Balok Laminasi Kombinasi antara Kayu Sengon dan Kayu Jati dengan Perekat Lem Epoxy. Skripsi. Fakultas Teknik, Universitas Muhamadiyah Surakarta, Surakarta. 